\title{
Relationship between functional fitness, medication costs and mood in elderly people
}

\author{
Michelli luciana Massolini laureano ${ }^{1 *}$, Raul Agostinho Martins ${ }^{2}$, Nuno M. Sousa², Aristides M. Machado-Rodrigues², \\ João Valente-Santos ${ }^{2}$, Manoel João Coelho-e-Silva²
}

${ }^{1}$ Institute of Social Sciences, Education and Zootechnics (ICSEZ), Federal University of Amazonas, Parintins, AM, Brazil ${ }^{2}$ Faculty of Sports Science and Physical Education (FCDEF), University of Coimbra, Coimbra, Portugal

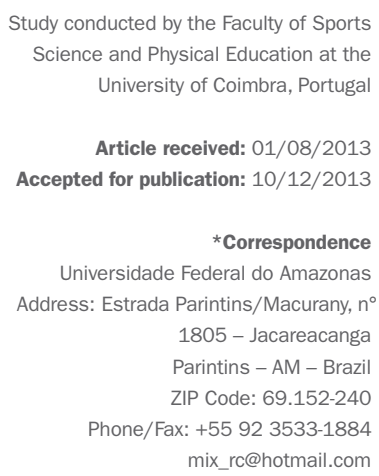

\section{SUMMARY}

Objective: to verify if functional fitness (FF) is associated with the annual cost of medication consumption and mood states (MSt) in elderly people.

Methods: a cross-sectional study with 229 elderly people aged 65 years or more at Santa Casa de Misericórdia de Coimbra, Portugal. Seniors with physical and psychological limitations were excluded, as well as those using medication that limits performance on the tests. The Senior Fitness Test was used to evaluate FF, and the Profile of Mood States - Short Form to evaluate the MSt. The statistical analysis was based on Mancova, with adjustment for age, for comparison between men and women, and adjustment for sex, for comparison between cardiorespiratory fitness quintiles. The association between the variables under study was made with partial correlation, controlling for the effects of age, sex and body mass index.

Results: an inverse correlation between cardiorespiratory fitness and the annual cost of medication consumption was found ( $\mathrm{p}<0.01)$. FF is also inversely associated with MSt $(\mathrm{p}<0.05)$. Comparisons between cardiorespiratory fitness quintiles showed higher medication consumption costs in seniors with lower aerobic endurance, as well as higher deterioration in MSt $(\mathrm{p}<0.01)$.

Conclusion: elderly people with better FF and, specifically, better cardiorespiratory fitness present lower medication consumption costs and a more positive MSt.

Uniterms: physical functional fitness, medication, mood states, elderly.

\section{INTRODUCTION}

The World Health Organization (WHO) estimates a 22\% increase in the prevalence of people aged over 60 years by $2050^{1}$. This growth has been attributed to technological advancements in the area of health, healthier behaviors ${ }^{2}$ and a reduction in birth rates. ${ }^{3,4,5}$

Physical functional fitness (FF), generally dimensioned in terms of the ability and independence to safely carry out day-to-day activities, ${ }^{6}$ has a direct impact on the quality of life ${ }^{7}$ of elderly people, and is one of the representative factors for the evaluation of health, directly related to physical activity levels. On the other hand, some authors have demonstrated that levels of physical activity are inversely related to the number of medications used by the elderly. ${ }^{8}$
The quality of life of the elderly is influenced by physical and functional aspects, as well as sociological and psychological aspects, with mood interpreted as the set of emotional states experienced by each person in their daily lives. ${ }^{9}$ The emotional dimension is connected to various feelings, whether negative (tension, anger, fatigue and depression) or positive (self-esteem, vigor and wellbeing) and is therefore associated with the individual's health and quality of life. ${ }^{10}$

In the elderly, it has been verified that there is greater vulnerability to iatrogenesis, side effects and adverse reactions to medication and, on the other hand, the benefits obtained with increased drug treatment do not translate into a future reduction in the use of medication. ${ }^{11}$ 
All of these aspects have an impact on the health and quality of life of this population, therefore, understanding the type of associations established between FF, the medication consumption costs and mood states (MSt) is of major relevance.

The evaluation of physical fitness should focus on the capacity of the musculoskeletal, cardiorespiratory and neurological systems through characterization of parameters such as aerobic fitness, muscular endurance, flexibility, agility and bodily composition. ${ }^{12}$ The Senior Fitness Test, ${ }^{12}$ used in the present study was translated and validated for the Portuguese population, and is easily applied and understood, with normative values that enable results to be compared. ${ }^{13,14}$

The evaluation of mood states was conducted using the Profile of Mood States - Short Form (POMS-SF) where six mood states are used: tension, depression, anger, vigor, fatigue and confusion. This questionnaire is composed of a five point Likert scale that describes different levels of feelings and was translated and validated for the Portuguese population. ${ }^{15,16}$

Given that presented above, the intention of this study was to verify if physical fitness is associated with the cost of medication consumption and mood in elderly people.

\section{Methods}

Study design and participants

A cross-sectional study was conducted with the participation of 229 seniors aged between 65 and 95 years, including 169 women ( $75 \pm 8$ years) and 60 men $(74 \pm 7$ years) originating from the long-term residential institution Santa Casa de Misericórdia de Coimbra, Portugal. The participants were kept on similar diets in terms of caloric and nutritional intake, controlled by a nutritionist, and any medication dosages, including salicylate and statins, remained unchanged during the study.

The investigation exclusion criteria were considered as all physical or psychological conditions that could interfere in the capacity to undertake the tests requested and the use of medication that might influence functional performance or the interpretation of the results.

The data was collected in five sessions, with the first used to collect anthropometric data the second for application of the POMS-SF and the measurement of hemodynamic variables, the third for application of the Senior Fitness Test in the form of a circuit, with the exception of the " 6 minute walk" test, which was held in the fourth session. In the last session the data relating to medication consumption was collected.
All of the participants gave their free and clarified consent after being informed of the potential risks and/ or discomfort associated with the tests. The study is in accordance with the laws of Portugal and was approved by the scientific council at the University of Coimbra.

\section{Anthropometric evaluation}

The anthropometric measurements were conducted in a separate room in order to guarantee the privacy of the participants. Body mass (BM) was determined using portable scales (Seca ${ }^{\circledR}$, model 770 , Germany) with a precision of $0.1 \mathrm{~kg}$. The waist circumference (WC) was measured on the narrowest part of the trunk, above the navel and below the xiphoid process using a retractable fiberglass measuring tape (Hoechstmass-Rollfix ${ }^{\circledR}$, Germany) with a precision of 0.1 centimeters. Height was determined using a portable stadiometer (Seca Bodymeter ${ }^{\circledR}$, model 208, Germany) with a precision of 0.1 centimeters. The Body Mass Index (BMI) was calculated using the BM and height.

\section{Physical fitness evaluation}

Physical fitness was evaluated using the Senior Fitness Test, ${ }^{7,12}$ translated and validated for the Portuguese population ${ }^{13}$ and constituted by the following tests:

i) the chair stand test, to evaluated the strength and endurance of the lower limbs;

ii) the arm curl test, to evaluate the strength and endurance of the upper limbs;

iii) the chair sit-and-reach test, to evaluate the flexibility of the lower limbs;

iv) the back scratch test, to evaluate the flexibility of the upper limbs;

v) the 8-foot up-and-go test, to evaluate agility, speed and dynamic balance and;

vi) the 6-minute walk test, to evaluate aerobic endurance.

\section{Evaluation of hemodynamic variables}

Resting systolic blood pressure (SBP) and diastolic blood pressure (DBP) were determined using the auscultatory method with the use of a sphygmomanometer (brand HICO, model HM 1001, Germany) and stethoscope (brand HICO, model HM-3005, Germany). The participants were placed in a seated position in accordance with the procedures recommended by the American College of Sports Medicine (ACSM) for the evaluation of resting blood pressure and pulse, ${ }^{17}$ with the latter evaluated using telemetry by Polar ${ }^{\circledR}$ (Polar S-810i, Finland) monitors during the walk test. 


\section{Mood evaluation}

Mood states were determined using the POMS-SF, ${ }^{16}$ which is composed of 22 items grouped into 6 dimensions or subscales: tension-anxiety (4 items), depression (5 items), irritation-hostility (3 items), vigor-activity (4 items), fatigue-inertia (4 items) and confusion (2 items). The total mood disturbance (TMD) was calculated from the difference between the positive dimension (vigor) and the negative ones (tension, depression, irritation, confusion and fatigue). The participants completed the questionnaires in a quiet room and the researcher was available during application in order to help with any queries in relation to completion of the instrument.

\section{Medication consumption evaluation}

Medication consumption was assessed by consulting the computerized records of each of the participant's family physicians. It is obligatory for the individual records of each patient to state all of the medication prescribed by the family physician. Only medication consumed regularly was considered, such as that for chronic diseases. Self-medication was not considered in this study. The amount of medication consumed annually was calculated using the prescribed dosage. The annual cost for each medication and the sum of the annual cost of all medication for each participant was calculated using the selling price to the public in Portugal in 2011.

\section{Statistical analysis of the data}

The data is presented as average values and standard variations and the variations in relation to normality and homogeneity were tested using the Kolmogorov-Smirnov test. The comparison between males and females was undertaken using the Mancova, adjusted for age. The comparison between the quintiles of the distanced covered in the 6-minute walk test was also undertaken using the Mancova, adjusted for the effects of sex. The association between the variables under study was undertaken with a particle correlation adjusted for age, sex and BMI. Data analysis was obtained using SPSS V. 19.0 (SPSS Inc, Chicago, IL, USA). Statistical significance was established to the level of $\mathrm{p}<0.05$.

\section{RESULTS}

All of the participants fulfilled the eligibility requirements. As pert Table 1, in the simple anthropometric variables height, body mass and waist circumference - men presented higher average values than women $(\mathrm{p}<0.01)$, while the waist-to-height ratio (WHtR) was similar in gender, as well as the SBP and DBP ( $>>0.05)$. Conversely, the BMI $(p<0.05)$ and $\mathrm{HR}_{\text {rep }}(\mathrm{p}<0.01)$ were higher in women.
TABLE 1 Description of the participants in terms of anthropometric and hemodynamic variables and functional fitness, mood states and annual medication consumption costs, adjusted for age for comparison between sexes (Coimbra, Portugal, 2012)

\begin{tabular}{|c|c|c|c|c|c|}
\hline & \multicolumn{2}{|l|}{$\begin{array}{l}\text { Women } \\
(N=169)\end{array}$} & \multicolumn{2}{|l|}{$\begin{array}{l}\text { Men } \\
(N=60)\end{array}$} & \multirow[t]{2}{*}{$\mathrm{p}$} \\
\hline & Min - Max & Med (SD) & Min - Max & $\begin{array}{l}\text { Med } \\
(\mathrm{SD})\end{array}$ & \\
\hline Age (years) & 65 to 95 & $75(8)$ & 65 to 92 & $74(7)$ & 1 \\
\hline Height $(\mathrm{cm})$ & 139 to 166 & $152(6)$ & 141 to 185 & $164(9)$ & $<0.01 * *$ \\
\hline Body mass (kg) & 46 to 91 & $67.6(9.8)$ & 38 to 105.8 & $75(14.4)$ & $<0.01 * *$ \\
\hline $\mathrm{BMI}\left(\mathrm{kg} / \mathrm{m}^{2}\right)$ & 19.2 to 42.2 & $29.3(4.2)$ & 17.3 to 39.3 & $27.7(4.3)$ & $0.02 *$ \\
\hline $\begin{array}{l}\text { Waist circumf } \\
(\mathrm{cm})\end{array}$ & 59 to 122 & $96(10)$ & 74 to 127 & $101(11)$ & $<0.01 * *$ \\
\hline WHtR & 0.39 to 0.86 & $0.63(08)$ & 0.49 to 0.75 & $0.62(07)$ & 0.15 \\
\hline $\mathrm{SBP}(\mathrm{mmHg})$ & 86 to 180 & $135(16)$ & 106 to 180 & $133(14)$ & 0.49 \\
\hline $\mathrm{DBP}(\mathrm{mmHg})$ & 50 to 116 & $77(12)$ & 59 to 101 & $76(9)$ & 0.84 \\
\hline $\begin{array}{l}\text { Resting HR } \\
\text { (beats/min) }\end{array}$ & 46 to 100 & $71(9)$ & 48 to 86 & $67(7)$ & $<0.01 * *$ \\
\hline $\begin{array}{l}\text { Lower strength } \\
\text { (reps/30s) }\end{array}$ & 2 to 23 & $12(5)$ & 3 to 23 & $13(5)$ & 0.49 \\
\hline $\begin{array}{l}\text { Upper strength } \\
\text { (reps/30s) }\end{array}$ & 1 to 28 & $13(6)$ & 3 to 20 & $12(4)$ & $0.03 *$ \\
\hline $\begin{array}{l}\text { Lower flexibility } \\
(\mathrm{cm})\end{array}$ & -52 to 30 & $-5(14)$ & $-12(12)$ & $-48(14)$ & $0.01 * *$ \\
\hline $\begin{array}{l}\text { Upper flexibility } \\
(\mathrm{cm})\end{array}$ & -71 to 10 & $-19(17)$ & -71 to 21 & $-25(19)$ & $<0.01 * *$ \\
\hline $\begin{array}{l}\text { Agility and } \\
\text { balance (s) }\end{array}$ & 3.8 to 55 & $10.6(7.5)$ & 4 to 36.7 & $9.3(5.5)$ & 0.22 \\
\hline Distance (m) & 60 to 728 & $392(151)$ & 65 to 750 & 449 (149) & $<0.01^{* *}$ \\
\hline Tension & 0 to 14 & $4(3.3)$ & 0 to 14 & $4.2(3.5)$ & 0.67 \\
\hline Depression & 0 to 18 & $4.6(4.3)$ & 0 to 19 & $5.1(5.5)$ & 0.36 \\
\hline Irritation & 0 to 8 & $1.8(1.8)$ & 0 to 10 & $2.3(2.3)$ & 0.07 \\
\hline Vigor & 0 to 16 & $8(3.9)$ & 0 to 16 & $7.3(3.6)$ & 0.19 \\
\hline Fatigue & 0 to 14 & $4.1(3.4)$ & 0 to 12 & $4.1(3.2)$ & 1 \\
\hline Confusion & 0 to 8 & $1.5(1.9)$ & 0 to 8 & $1.8(2.3)$ & 0.29 \\
\hline TMD & 85 to 156 & $108(15)$ & 84 to 151 & $110(16)$ & 0.28 \\
\hline $\begin{array}{l}\text { Medication } \\
\text { cost }(€)\end{array}$ & 26 to 4.729 & $951(847)$ & 86 to 2.833 & $877(615)$ & 0.55 \\
\hline
\end{tabular}

* Differences between sexes $(p \leq 0.05)$; ** Differences between sexes $(p \leq 0.01)$.

BMI - Body Mass Index; Waist Circumf - waist circumference; WHtR- Waist to height ratio; BP blood pressure; HR - heart rate; TMD - total mood disturbance. 
Reading Table 1 we can see that women presented greater fitness in respect to upper strength $(\mathrm{p}<0.05)$ and upper and lower flexibility $(\mathrm{p}<0.01)$, while men presented better cardiorespiratory fitness performance $(\mathrm{p}$ $<0.01)$. Lower strength and agility, speed and dynamic balance are similar in men and women ( $p>0.05)$. Table 1 also shows that men and women obtained similar mood states - tension, depression, irritation, confusion, vigor, fatigue and TMD - and similar annual medication costs $(\mathrm{p}>0.05)$.

In the study of the association between physical fitness and the annual cost of medication consumption (Table 2), a negative correlation was found between cardiorespiratory fitness and medication costs $(r=-0.185$; $p<0.01)$. The other physical fitness components did not present significant correlations although there was a tendency toward an inverse association.

In Table 2 we can note that cardiovascular fitness is inversely associated with tension $(r=-0.339 ; \mathrm{p}<0.01)$, depression $(r=-0.382 ; \mathrm{p}<0.01)$, fatigue $(\mathrm{r}=-0.345 ; \mathrm{p}<0.01)$, confusion $(r=-0.384 ; p<0.01)$ and TMD $(r=-0.394$; $\mathrm{p}<0.01)$ and directly associated with vigor $(r=0.300$; $\mathrm{p}<0.01)$. The remaining physical fitness components also present a similar tendency toward an association with the mood states analyzed, enabling it to be affirmed that, in general, negative mood states are inversely associated with FF and positive mood states are directly associated with FF.

TABLE 2 Partial correlation between variables adjusted for the effects of sex, age and BMI (Coimbra, Portugal, 2012)

\begin{tabular}{|c|c|c|c|c|c|c|}
\hline & $\begin{array}{l}\text { Lower } \\
\text { strength }\end{array}$ & $\begin{array}{l}\text { Upper } \\
\text { strength }\end{array}$ & $\begin{array}{l}\text { Lower } \\
\text { flexibility }\end{array}$ & $\begin{array}{l}\text { Upper } \\
\text { flexibility }\end{array}$ & $\begin{array}{l}\text { Agility and } \\
\text { balance }\end{array}$ & $\begin{array}{l}\text { Aerobic } \\
\text { endurance }\end{array}$ \\
\hline \multicolumn{7}{|l|}{ Medication cost } \\
\hline correlation & -0.129 & -0.109 & -0.051 & -0.057 & 0.039 & -0.185 \\
\hline significance & 0.06 & 0.11 & 0.45 & 0.4 & 0.56 & $<0.01 * *$ \\
\hline \multicolumn{7}{|l|}{ Tension } \\
\hline correlation & -0.282 & -0.225 & -0.119 & -0.26 & 0.107 & -0.339 \\
\hline significance & $<0.01 * *$ & $<0.01 * *$ & 0.08 & $<0.01 * *$ & 0.11 & $<0.01 * *$ \\
\hline \multicolumn{7}{|l|}{ Depression } \\
\hline correlation & $-0,337$ & -0.254 & -0.217 & -0.317 & 0.116 & -0.382 \\
\hline significance & $<0.01 * *$ & $<0.01 * *$ & $<0.01 * *$ & $<0.01 * *$ & 0.09 & $<0.01 * *$ \\
\hline \multicolumn{7}{|l|}{ Irritability } \\
\hline correlation & -0.012 & -0.051 & -0.131 & 0.031 & -0.013 & 0.015 \\
\hline significance & 0.87 & 0.45 & $0.05^{*}$ & 0.64 & 0.85 & 0.82 \\
\hline \multicolumn{7}{|l|}{ Vigor } \\
\hline correlation & 0.278 & 0.272 & 0.093 & 0.095 & -0.026 & 0.3 \\
\hline significance & $<0.01 * *$ & $<0.01 * *$ & 0.17 & 0.16 & 0.7 & $<0.01 * *$ \\
\hline \multicolumn{7}{|l|}{ Fatigue } \\
\hline correlation & -0.276 & -0.215 & -0.081 & -0.287 & 0.099 & -0.345 \\
\hline significance & $<0.01 * *$ & $<0.01 * *$ & 0.23 & $<0.01 * *$ & 0.14 & $<0.01 * *$ \\
\hline \multicolumn{7}{|l|}{ Confusion } \\
\hline correlation & -0.342 & -0.28 & -0.236 & -0.429 & 0.228 & -0.384 \\
\hline significance & $<0.01 * *$ & $<0.01^{* *}$ & $<0.01 * *$ & $<0.01 * *$ & $<0.01 * *$ & $<0.01 * *$ \\
\hline \multicolumn{7}{|l|}{ TMD } \\
\hline correlation & -0.345 & -0.289 & -0.183 & -0.296 & 0.117 & -0.394 \\
\hline significance & $<0.01 * *$ & $<0.01 * *$ & $<0.01 * *$ & $<0.01 * *$ & 0.08 & $<0.01^{* *}$ \\
\hline
\end{tabular}

* Association between variables $(p \leq 0.05)$; ${ }^{*}$ Association between variables $(p \leq 0.01)$.

TMD - Total mood disturbance 


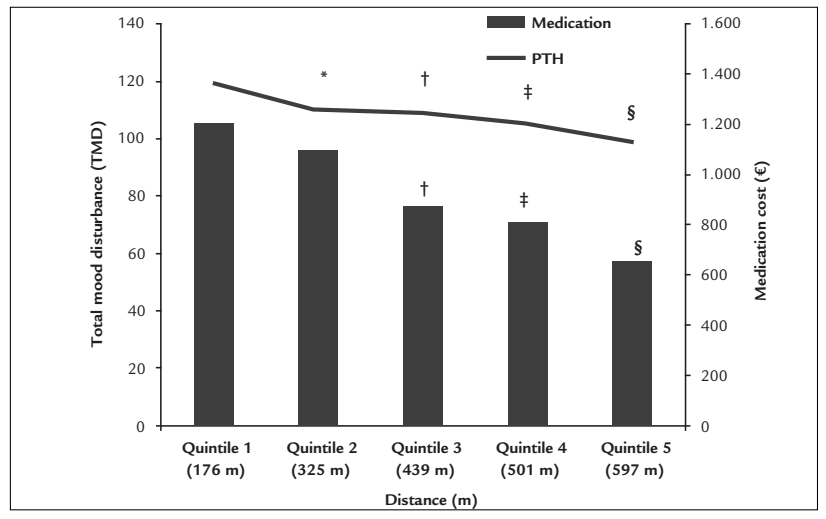

FIGURE 1 Annual cost of medication consumption $(€)$ and total mood disturbance in relation to distance traveled in the 6-minute walk test (Coimbra, Portugal, 2012).

* Differences between quintile 1 and quintile $2(p \leq 0.01)$; $\uparrow$ differences between quintile 1 and quintile $3(p \leq 0.01)$; $\neq$ differences between quintile 1 and quintile $4(p \leq 0.01)$; $\S$ differences between quintile 1 and quintile 5 and between quintile 2 and quintile $5(p \leq 0.01)$.

Figure 1 illustrates the TMD and annual medication cost in each of the quintiles of the distance traveled in the 6-minute walk test. The participants in quintile 1 , who only walked $176 \mathrm{~m}$ on average, presented a higher TMD and higher medication consumption cost, and a progressive reduction was verified as the distance traveled increased, so that participants in quintile 5 , who walked $597 \mathrm{~m}$ on average, had the lowest TMD and lowest medication costs. In terms of TMD, differences were significant $(\mathrm{p}<0.01)$ between quintile 1 and quintile 2 , between quintile 1 and quintile 3 , between quintile 1 and quintile 4, between quintile 1 and quintile 5 and between quintile 2 and quintile 5 . For the cost of medication, differences were significant $(p<0.01)$ between quintile 1 and quintile 3 , between quintile 1 and quintile 4 , between quintile 1 and quintile 5 and between quintile 2 and quintile 5 . Taking the participants from quintile 1 as a reference, those from quintile 2 spent 9\% less on medication, those from quintile 3 spent $28 \%$ less, those from quintile 4 spent $33 \%$ less and those from quintile 5 spent $46 \%$ less.

\section{Discussion}

The description of the participants is similar to that found in other studies, where seniors practicing physical activity or not presented a BMI value classified as overweight. ${ }^{7,8,18,19}$ This fact is predictable in this age range, given that over the years there is a decrease in lean mass and an increase in fat mass, ${ }^{19}$ but is not acceptable, given that this is associated with an increase in the number of comorbidities. ${ }^{20}$ Furthermore, the values found for the waist circumference are high compared to the cut-off values of the International Diabetes
Federation (IDF) ${ }^{21}$ and the NIH (National Institutes of Health $)^{22}$ revealing central obesity. This situation is a predictor of health complications in seniors ${ }^{19}$ and an increased risk of cardiovascular diseases, indicated as the major cause of mortality and morbidity. ${ }^{23}$

$\mathrm{HR}_{\text {rep }}$ is a cardiac conditioning indicator and showed high values for females. Despite the SBP and DBP having similar values between men and women, the participants in this study are pre-hypertensive according to the classification given by the JCN-VII ${ }^{24}$ (The Seventh Report of the Joint National Committee on Prevention, Detection, Evaluation and Treatment of High Blood Pressure) for SBP.

All of these variables show the need to improve anthropometric and hemodynamic aspects in the participants, reducing the incidence of diseases and, consequently, lowering the use of medication. Various studies have investigated the effects of physical activity on the elderly and demonstrated it to be beneficial for reducing heart rate, ${ }^{25,26}$ and adjuvant in chronic diseases such as congestive heart failure and chronic pulmonary disorder, ${ }^{23}$ as well as reducing the risk of developing hypertension. $8,20,26,27$

In addition to chronic and degenerative diseases, attention should be given to functional incapacity, which may reduce socialization and affect the sense of wellbeing, ${ }^{28}$ as well as the emotional state of seniors, given that in this age range human beings encounter a series of factors that are emotionally overwhelming. ${ }^{23,29,30,31}$ There are studies proving that elements such as higher intake of medication, internal and external stress ${ }^{32}$ and eating disorders ${ }^{24}$ contribute to making depression one of the diseases with a growing prevalence among the elderly, compromising their quality of life. ${ }^{32,33}$

In this study, the participants demonstrated similar physical fitness and mood states in the general context presented, for men and women, as well as similar medication consumption costs. However, when considering aerobic endurance, measured using the 6-minute walk test, it was verified that men obtained better results, as well as lower medication costs, although this was not statistically significant. We can highlight that aerobic capacity interferes in cardiac, ${ }^{34,35}$ pulmonary ${ }^{34}$ and blood pressure $^{35,36}$ functions and, as presented in Table 1, women obtain inferior performance to men, with a concomitant tendency for higher medication costs.

When correlating the physical fitness variables adjusted for the effects of sex, age and BMI, it was verified that the result becomes statistically significant for aerobic endurance, proving that the better this capacity is in seniors, the lower the social and individual cost for medication. Results found in similar studies have indicated 
that better performance in aerobic capacity is associated with lower expenditure on medication. ${ }^{37,38}$ Other studies of the same kind but which associated specific sports modalities obtained positive results, with higher values in the physical and functional fitness tests providing lower annual costs associated with the consumption of medication. ${ }^{32,39}$ Therefore, knowing that the increase incidence of chronic health problems makes seniors large consumers of medication ${ }^{11}$ and that this may be an indicator of their general state of health, ${ }^{9}$ reducing it is a question of public health and is possible through encouraging the practice of physical activity, $8,32,37,38,39$ which is proven to result in social and psychological benefits, as well as biological/physiological ones. . $23,26,27,32,37,38,39$

In addition to the proven benefits, when associating physical activity with the consumption of medication, despite the literature being scarce, there is work such as that by Codogno et al..$^{40}$ which, when comparing sedentary and active groups of those with type 2 Diabetes Mellitus, verified medication consumption $23 \%$ higher in the sedentary group when considering only medication for the treatment of diabetes, and $128 \%$ higher when considering medication for the treatment of other diseases. Another study that proved the effectiveness of physical activity on reduction in the use of medication by Bertoldi et al. ${ }^{41}$ analyzed a sample of Brazilian adults and verified that the level of physical activity was inversely associated with the prevalence and number of medications used. They also verified that the results were confirmed in those with chronic diseases and that even after the diseases became present, active individuals have a lower propensity to consume medication. The results of these studies indicated a need to incentivize the practice of physical activity as a mechanism for the reduction of medication consumption. These findings are in accordance with this research, given that the association between physical fitness and the regular practice of physical activity has been well established. This practice also clearly contributes to improving mood, which ensures better socialization, minimizes emotional disorders and contributes to increasing quality of life.

A strong point of this study is the fact that it is the first to associate physical fitness, medication consumption costs and mood states. Up to now, no publication has been found in relation to this triple association. There are studies showing the association between mood states and medication consumption and, separately, physical fitness and medication consumption. ${ }^{32,37,38,39}$

Some studies were encountered showing an association between physical and functional fitness and mood states. In the work undertaken by Marques, ${ }^{38}$ which evaluated different groups (control versus physical exercise) it was verified that the group submitted to training obtained higher and statistically significant values in the vigor dimension when compared to the control group. The same work also indicated improvements in the physical fitness of the exercise group. The study published by Martins et al., ${ }^{42}$ analyzed the effects of a sixteen-week strength training and aerobic training program on the mood states of seniors using the same instruments in the present study, verifying that the two training groups improved in terms of physical fitness and that this contributed to improvements in mood. Both articles cited presented results in accordance with the findings herein. Likewise, Teixeira et al. ${ }^{43}$ verified that nineteen weeks of exercise reduced the levels of depression, tension, fatigue and irritation and increased the level of vigor, while in the same period the control group recorded a reduction in vigor and increase in the level of confusion. Similar to these findings, another study by Martins et al., ${ }^{44}$ also with an experimental group submitted to physical exercise and a control group, verified that the exercise group recorded a statistically significant reduction in depression, tension, fatigue and irritation levels, and an increase in vigor levels. Despite not being statistically significant, the confusion levels also presented a tendency to decrease. It is worth reiterating that despite the studies encountered relating to research with control and experimental groups, all report improvements in physical fitness owing to physical exercise and correlate this mood states, and are therefore have compatible parameters with the present study.

In this analysis, aerobic endurance was selected from the triple association between the annual cost of medication consumption, total mood disturbance and physical fitness, represented as the distance traveled in the 6-minute walk test, as this variable was highlighted in previous tests. Similarly, the TMD was used for mood states, with results consistent with previous correlations. The results encountered are unique and have no comparisons in the current literature, reflecting the need to direct public health policies to consider multidisciplinary issues in monitoring and treating seniors, given that in developed countries every dollar applied to prevention results in savings of 100 dollars in hospitalizations, which are always longer and have a higher cost for elderly patients. ${ }^{45}$ Furthermore, the reduction in medication consumption costs at the personal and family level improves the quality of life of this population, given that financial difficulties 
and the presence of diseases may negatively influence the quality of life of the elderly. ${ }^{46}$

Some limitations of this study should also be taken in account. Firstly, the sample was composed by seniors that are long-term residents of institutions (or care homes), and different results may be presented for other samples. Lastly, the POMS-SF was considered as being responded to sincerely by the participants, as despite being recognized as effective for the measurements proposed and presented herein, it is a subjective assessment tool.

\section{Conclusion}

Better physical fitness, with an emphasis on aerobic endurance, was significantly associated with lower medication consumption costs and better mood states in elderly people residing in long-term residential institutions. These findings suggest that one of the ways to reduce the cost of medication consumption, whether at the personal, family or State level, would be the regular practice of physical activity, capable of improving physical and functional fitness, social relationships and mood states in the elderly, and providing them with more quality of life.

\section{ACKNOWLEDGMeNTS}

The authors wish to thank for the Foundation for Science and Technology (FCT) for financing this study (Project Ref. PTDC/DES/111620/2009).

\section{Resumo}

Relações entre aptidão física funcional, custos com consumo de medicamentos e estados de humor em pessoas idosas

Objetivo: verificar se a aptidão física funcional (AFF) tem associação com o custo anual de consumo de medicamentos e com os estados de humor (EH) em pessoas idosas.

Métodos: estudo transversal com 229 idosos de 65 anos de idade ou mais da Instituição Santa Casa de Misericórdia de Coimbra, Portugal. Foram excluídos os idosos com limitações físicas e psicológicas e os que usavam medicamentos que condicionariam a realização dos testes. Foram utilizados a bateria Senior Fitness Test e o questionário Profile of Mood States - Short Form como instrumentos de coleta de dados. A análise estatística recorreu à Mancova, com ajuste de idade, para comparação entre homens e mulheres, e ajustada também para o sexo, para comparação entre quintis da aptidão cardiorrespiratória. A associação entre as variáveis de interesse foi fei- ta com a correlação parcial, corrigindo o efeito da idade, do sexo e do índice de massa corpórea.

Resultados: verificou-se a existência de correlação inversa entre a aptidão cardiorrespiratória e o custo anual de consumo de medicamentos $(\mathrm{p}<0,01)$. A AFF associou-se também inversamente com os EH ( $\mathrm{p}<0,05)$. As comparações entre os quintis da aptidão cardiorrespiratória revelaram maior consumo de medicamentos em idosos com menor resistência aeróbia, assim como maior deterioração dos $E H(p<0,01)$.

Conclusão: idosos com melhor AFF e, particularmente, melhor aptidão cardiorrespiratória apresentam menores custos com consumo de medicamentos e EH mais positivos.

Unitermos: aptidão física funcional; medicamentos; estados de humor; idoso.

\section{References}

1. Organização Mundial de Saúde (OMS) Guia Global das cidades amigas das pessoas idosas. Portugal: Fundação Calouste Gulbenkian; 2009 [cited 14 May 2012]. Available at: http://www.gulbenkian.pt/media/files/FTP_files/ pdfs/PGDesenvolvimentoHumano/ProjIdosos_GuiaCidades2009.pdf.

2. Organização Mundial de Saúde (OMS). Envelhecimento ativo: uma política de saúde. Trad. Suzana Gontijo. Brasília (DF): Organização Pan-Americana de Saúde; 2005. 60p.

3. INE I.P. Censos 2011. Resultados provisórios [Internet]. Lisboa: Instituto Nacional de Estatística; 2011 [cited 15 May 2012]. Available at: http://www. ine.pt/xportal/xmain?xpid=INE\&xpgid=ine_destaques\&DESTAQUESdest boui $=129675729 \&$ DESTAQUESmodo $=2$.

4. Instituto Brasileiro de Geografia e Estatística. População brasileira envelhece em ritmo acelerado. 2008. [cited 17 Sept 2012]. Available at: http://www. ibge.gov.br/home/presidencia/noticias/noticia_impressao.php?id_ noticia $=1272$.

5. Minayo MCS. O envelhecimento da população brasileira e os desafios para o setor saúde. Cad Saúde Pública. 2012;28(2):208-9.

6. Lima-Costa MF, Barreto SM, Giatti L. Condições de saúde, capacidade funcional, uso de serviços de saúde e gastos com medicamentos da população idosa brasileira: um estudo descritivo baseado na Pesquisa Nacional por Amostra de Domicílios. Cad Saúde Pública. 2003;19(3):735-43.

7. Rikli RE, Jones CJ. Senior fitness test manual. Champaign (Illinois): Human Kinetics Books; 2001. 176p.

8. Silva LJ, Azevedo MR, Matsudo S, Lopes GS. Associação entre níveis de atividade física e o uso de medicação entre mulheres idosas. Cad Saúde Pública. 2012;28(3): 463-71.

9. Biddle SJH. Emotion, mood and physical activity. In: Biddle SJH, Fox KF, Boutcher SH, editors. Physical activity and psychological well-being. London: Routledge; 2000. p.63-87.

10. Cavallini GM, Fagundes AP, Martins A, Miranda JK, Rodrigues M, Krug MR, Martins ES, Callegaro CC, Panda MDJ. A influência de um programa de exercícios físicos no estado de humor dos indivíduos cadastrados no esf/ primavera. In: XVI Seminário Interinstitucional de Ensino, Pesquisa e Extensão. XVI Mostra de Iniciação Científica e IX Mostra de Extensão; 2011. Cruz Alta (RS), Brasil.

11. Loyola Filho AI, Uchoa E, Lima-Costa MF. Estudo epidemiológico de base populacional sobre uso de medicamentos entre idosos na Região Metropolitana de Belo Horizonte, Minas Gerais, Brasil. Cad Saúde Pública. 2006;22(12):2657-67.

12. Rikli RE, Jones CJ. Development and validation of a functional fitness test for comunnity-residing older adults. J Aging Phys Act. 1999;7(2):129-61.

13. Sardinha L, Martins T. Uma nova bateria para a avaliação da aptidão física funcional da pessoa idosa. In: Barreiros J, Espanha M, Correia P, editors. 
Simpósio envelhecer melhor com a atividade física. Lisboa: FMH Edições, 1999. p.209-19.

14. Baptista F, Sardinha LB. Avaliação de aptidão física e do equilíbbrio de pessoas idosas - baterias de Fullerton. Cruz Quebrada: FMT Edições; 2005.

15. Viana MF, Almeida PL, Santos RC. Adaptação portuguesa da versão reduzida do Perfil de Estados de Humor - POMS. Análise Psicológica. 2001;1(19):7792.

16. Cruz J, Mota M. Adaptação e características psicométricas do "POMS-Profile of Mood States" e do "STAI - State Trait Anxiety Inventory". In: Gonçalves M, Ribeiro I, Araújo S, Machado C, Almeida L, Simões M, editors. Avaliação psicológica: formas e contextos. Braga: APPORT; 1997. v.5, p. 539-45.

17. ACSM (American College of Sports Medicine). ACSM's Guidelines for Exercising Testing and Prescription. Philadelphia: Lippincott Wiliams \& Wilkins; 2010.

18. Farinea N, Ricalde SR, Sivieri, J. Perfil nutricional e antropométrico de idosos participantes de um grupo de ginástica no município de Antônio Prado RS. RBCEH. 2010;7(3):393-04.

19. Santos DM, Sichieri R. Índice de massa corporal e indicadores antropométricos de adiposidade em idosos. Rev Saúde Pública. 2005;39(2):163-8.

20. Manuretti DB, Barbosa AR, Marucci MFN, Lebrão ML. Hipertensão arterial referida e indicadores antropométricos de gordura em idosos. Rev Assoc Med Bras. 2011;57(1):25-30.

21. International Diabetes Federation. The IDF Consensus Worldwide Definition of the Metabolic Syndrome. [cited 2012 Jul 31]. Available at: http://www. idf.org/webdata/docs/MetSyndrome_FINAL.pdf.

22. National Institutes of Health. Clinical Guidelines on the Identification, evaluation, and Treatment of Overweight and Obesity in Adults: The Evidence Report. c1998. National Heart, Lung, and Blood Institute, Bethesda; 1998.

23. Zaslavsky C, Gus I. Idoso. Doença cardíaca e comorbidades. Arq Bras Cardiol. 2002;79(6):635-9.

24. Joint National Committee on Prevention, Detection, Evaluation and Treatment of Hight Blood Pressure. The Seventh Report of the Joint National Committeen on Prevention, Detection, Evaluation And Treatment Of Hight Blood Pressure. National Institutes of Health; 2003. Publication n.03-5233. Available at: http:// www.nhlbi.nih.gov/guidelines/hypertension/express.pdf.

25. Menezes-Cabral RL, Silva-Dantas PM, Montenegro-Neto AN, Knackfuss MI. Efeitos de diferentes treinamentos e estilos de vida nos indicadores antropométricos e cardiocirculatórios no envelhecimento. Rev Salud Pública. 2009; 11(3):359-69.

26. Martins RA, Veríssimo MT, Coelho e Silva MJ, Cumming SP, Teixeira AM. Effects of aerobic and strength-based training on metabolic health indicators in older adults. Lipids Health Dis. 2010;9:76.

27. Pinto VLM, Meirelles LR, Farinatti PTV. Influência de programas não-formais de exercícios (doméstico e comunitário) sobre a aptidão física, pressão arterial e variáveis bioquímicas em pacientes hipertensos. Rev Bras Med Esporte. 2003;9(5):99-104.

28. Anjos DMC, Araujo IL, Barros VM, Pereira DAG, Pereira DS. Avaliação da capacidade funcional em idosos diabéticos. Fisioter Pesq. 2012;19(1):73-8.

29. Fechine BRA, Trompieri N. O processo de envelhecimento: as principais alterações que acontecem com o idoso com o passar dos anos. Rev Cient Int. 2012;20(1):106-32
30. Figueiredo VLM. Estilo de vida como indicador de saúde na velhice. Cienc Cog. 2007;12:156-64.

31. Mendes MRSSB, Gusmão JL, Faro ACM, Leite RCBO. A situação social do idoso no Brasil: uma breve consideração. Acta Paul Enferm. 2005;18(4):422-6.

32. Ferreira EEDBA. Gestão de custos com medicamentos, hidroginástica e qualidade de vida em pessoas idosas de Santarém [tese de mestrado]. Coimbra: Universidade de Coimbra; 2011. 112p.

33. Sass A, Gravena AAF, Pilger C, Mathias TAF, Marcon SS. Depressão em idosos inscritos no programa de controle de hipertensão arterial e diabetes mellitus. Acta Paul Enferm. 2012;25(1):80-5.

34. Hollemberg M, Yang J, Haight TJ, Tager IB. Longitudinal Changes in aerobic capacity: implications for concepts of aging. J Gerontol A Biol Sci Med Sci. 2006;61(8):851-8.

35. Pinto VLM, Meirelles LR, Farinatti PTV. Influência de programas não-formais de exercícios (domésticos e comunitários) sobre a aptidão física, pressão arterial e variáveis bioquímicas em pacientes hipertensos. Rev Bras Med Esporte. 2003;9(5):267-74.

36. Moraes WM, Souza PRM, Pinheiro MHNP, Irigoyen MC, Medeiros A, Koike MK. Programas de exercícios físicos baseado em frequência semanal mínima: efeitos na pressão arterial e aptidão física em idosos hipertensos. Rev Bras Fisioter. 2011;16(2):114-21. [cited 18 Sept 2012]. Available at: http://www. scielo.br/pdf/rbfis/2012nahead/pt_aop009_12_sci1040.pdf.

37. Biel JNG. Gestão de custos com medicamentos, aptidão física funcional e qualidade de vida em idosos institucionalizados do Concelho de Leiria [masters thesis]. [Coimbra (PT)]: Universidade de Coimbra; 2011. 134p.

38. Marques, J.M. Organização e gestão de um programa de exercício físico multicomponente: Efeitos no custo com medicação, aptidão física, imunidade, perfil metabólico, estado de humor e qualidade de vida em idosos [tese de mestrado]. [Coimbra (PT)]: Universidade de Coimbra; 2011. 148p.

39. Cruz ACM. Gestão de custos com medicamentos, natação e qualidade de vida em pessoas idosas de Santarém [tese de mestrado]. [Coimbra (PT)]: Universidade de Coimbra; 2011. 148p

40. Codogno JS, Fernandes RA, Monteiro HL. Práticas de atividade física e custo do tratamento ambulatorial de diabéticos tipo 2 atendidos e Unidades Básicas de Saúde. Arq Bras Endocrinol Metab. 2012;56(1):6-11.

41. Bertoldi AD, Hallal PC, Barros AJ. Physical activity and medicine use: evidence from a population-based study. BMC Public Health. 2006; 6:224.

42. Martins R, Coelho e Silva M, Pindus D, Cumming S, Teixeira A, Veríssimo M. Effects of strength and aerobic based training on functional fitness, mood and the relationship between fatiness and mood in older adults. J Sports Med Phys Fitness. 2011;51(3):489-96.

43. Teixeira AM, Martins R, Martins M, Cunha MR. Changes in functional fitness, mood states and salivar IgA levels after exercise training for 19 weeks in ederly. Int J Applied Sports Sci. 2008;20(2):16-26.

44. Martins R, Rosado F, Cunha MR, Martins M, Teixeira AM. Exercício físico, IgA salivar e estados emocionais em pessoas idosas. Motricidade. 2008;4(1):5-11.

45. Del Pozzo O. Políticas públicas de saúde para idosos no Brasil.. Brasil: Revista Portal de Divulgação. 2012;9. [cited 31 Jul 2012]. Available at: http://www. portaldoenvelhecimento.org.br/revista/index. php.

46. Cartaxo HGO, Silva EAPC, Santos ARM, Siqueira PGBS, Pazzola CM, Freitas CMSM. Percepção de idosas sobre o envelhecimento com qualidade de vida: subsídio para intervenções públicas. Rev Rene. 2012;13(1):158-68. 